\title{
EFEKTIFITAS MEDIA BONEKA UPIN-IPIN DALAM MENINGKATKAN KEMAMPUAN MENGENAL HURUF HIJAIYAH PADA KELOMPOKA DI POS PAUD BOUGENVILLE 2 NGAWEN SIDAYU GRESIK
}

\author{
Nina Nuriyah Maarif \\ Sekolah Tinggi Agama Islam Daruttaqwa Gresik, Indonesia \\ Email: ninamaarif77@gmail.com \\ Nur Azizah \\ Guru PAUD Bougenville 2 Ngawen Gresik, Indonesia \\ Email: nur88azizah1@gmail.com
}

\begin{abstract}
This article discusses the effectiveness of using the Upin-Ipin doll media in increasing the ability of a group of students in the early childhood education (PAUD) in recognizing hijaiyah letters at Pos PAUD Bougenville 2 Ngawen Sedayu Gresik. By using the classroom action research method, this study shows that the usage of the Upin-Ipin doll has resulted in an increase the ability of students of Pos PAUD Bougenville 2 Ngawen Sidayu Gresik in reading hijaiyah letters. It can be seen from the increase of each student's score in cycle I (75\%) to $92 \%$ in cycle II. It is also found that the overall percentage in cycle I $(50 \%)$ increases $(80 \%)$ in the overall percentage in cycle II.
\end{abstract}

Kaywords: Puppet Media, Upin Ipin, Hijaiyah Letter, PAUD Bougenville 2

\begin{abstract}
Abstrak: Artikel ini membahas peran media pembelajaran boneka Upin-Ipin dalam meningkatkan kemampuan kelompok A siswa pendidikan anak usia dini (Paud) dalam mengenal huruf hijaiyahdi Pos Paud Bougenville 2 Ngawen Sedayu Gresik. Dengan menggunakan metode penelitian tindakan kelas (PTK), yang menggunakan dua siklus, studi ini menujukkan bahwa dengan menggunakan boneka Upin-Ipin tampak adanya peningkatan kemampuan siswa POS PAUD Bougenville 2 Ngawen Sidayu Gresik dalam membaca huruf hijaiyah.Hal ini dapat dilihat dari hasil nilai per-siswa $75 \%$ pada siklus I, yang lebih lanjut meningkat menjadi $92 \%$ pada siklus II. Demikian pula didapati dari prosentase keseluruhan pada siklus I (50\%)meningkat (80\%)pada prosentase keseluruhan pada siklus II.
\end{abstract}

Kata kunci: Media Boneka, Upin Ipin, Huruf Hijaiyah, PAUD Bougenville 2

\section{Pendahuluan}

Pendidikan adalah usaha sadar dan terencana untuk mewujudkan suasana belajar dan proses pembelajaran agar peserta didik secara aktif mengembangkan potensi dirinya untuk memiliki kekuatan spiritual keagamaan, pengendalian diri, kepribadian, kecerdasan, akhlak mulia, serta keterampilan yang diperlukan dirinya, masyarakat, bangsa dan negara. ${ }^{1}$

Tujuan pendidikan nasional akan berhasil apabila pelaksanaan pendidikan dilakukan sejak usia dini, dimana pendidikan anak usia dini digolongkan dalam pendidikan prasekolah.

\footnotetext{
${ }^{1}$ Memahami Paradigma Baru Pendidikan Nasional dalam Undang-Undang Sistem Pendidikan Nasional, (Jakarta : Departemen Agama RI, 2003), hal. 34
} 
Pendidikan prasekolah merupakan pondasi bagi keberhasilan pendidikan pada jenjang pendidikan beikutnya, yaitu pendidikan dasar di Sekolah Dasar, karena perkembangan kepribadian, sikap mental dan intelektual dibentuk pada usia dini.

Kualitas pendidikan masa kanak-kanak atau masa prasekolah menjadi cermin kualitas bangsa yang akan datang. Hal itu dikarenakan masa kanak-kanak merupakan masa "emas" atau masa yang tepat untuk memulai memberikan berbagai stimulus untuk merangsang anak agar dapat berkembang secara optimal. Pendidikan prasekolah merupakan pendidikan yang bermakna untuk mengembangkan seluruh potensi yang dimiliki anak tanpa merusak kondisi fisik dan psikisnya. Hal ini seperti disebutkan dalam Dokumen Standar Kompetensi Taman Kanak-Kanak dan Raudlatul Athfalbahwa, "Tujuan Pendidikan Taman Kanak-Kanak dan Raudlatul Athfal adalah membantu anak dan nilai-nilai agama, sosial emosional, kognitif, bahasa fisik/motorik, kemandirian dan seni untuk siap memasuki pendidikan dasar"2.

Taman kanak-kanak merupakan salah satu bentuk pendidikan yang menyediakan pendidikan dini bagi anak usia 4 tahun sampai memasuki pendidikan dasar. Usia 4-6 tahun merupakan masa peka bagi anak. Masa peka merupakan masa terjadinya pematangan fungsi-fungsi fisik dan psikis yang siap merespon stimulasi dari lingkungan untuk meletakkan dasar pertama dalam mengembangkan kemampuan fisik, kognitif, bahasa, sosial-emosional, seni, kemandirian agar pertumbuhan dan perkembangan anak.

Lebih lanjut, usia prasekolah merupakan usia yang efektif untuk mengembangkan potensi yang dimiliki anak. Salah satu kemampuan anak yang perlu dikembangkan adalah kemampuan dasar bahasa Arab sebagai bahasa al-Qur'an. Pada anak usia prasekolah kemampuan bahasa Arab ditekankan pada pengenalan huruf-huruf bijaiyah, dengan media yang tepat agar stimuli yang diberikan dapat terekam pada ingatan anak dengan baik. Oleh karena itu, agar pencapaian tujuan tersebut dapat optimal maka perlu adanya perencanaan Kegiatan Belajar Mengajar (KBM) di TK yang meliputi bagaimana memilih bahan atau media, sumber belajar dan metode atau teknik kegiatan yang tepat, sehingga guru dapat menciptakan lingkungan belajar yang menarik dan bermakna.

Namun demikian, fakta selama ini, masih banyak pembelajaran di Taman Kanak-Kanak/ Raudlatul Athfalyang bersifat tradisional, yakni penyampaian materi yang dilakukan oleh pendidik biasanya hanya dilaksanakan dengan metode ceramah atau bercakap-cakap saja, sehingga dalam menerima materi atau pengetahuan, minat anak sangat kurang. Kurangnya minat anak dalam mengikuti pembelajaran ini akan mengakibatkan tujuan pembelajaran tidak dapat tercapai secara optimal.

Selain itu, belajar menulis huruf bijaiyah juga sangat sulit dalam praktek penulisannya, sehingga ketika anak-anak disuruh mempraktekkan menulis huruf hijaiyah kurang mampu mengaplikasikan apa yang sudah disampaikan oleh guru. Pada dasarnya anak lebih menyukai hal-hal yang baru, anak juga lebih peka terhadap bentuk dan warna. Untuk mengatasi hal tersebut, maka salah satu cara yang dilakukan dalam pembelajaran dengan menggunakan permainan. Ini karena pada hakikatnya semua anak suka bermain. Dalam kehidupan anak, bermain mempunyai arti yang sangat penting. Setiap anak yang sehat selalu mempunyai dorongan untuk bermain sehingga dapat dipastikan bahwa anak yang tidak bermain-main umumnya sedang dalam keadaan sakit baik jasmaniah maupun rohaniahnya. Kebutuhan-kebutuhan jasmaniah dan rohaniah anak yang mendasar sebagian besar dipenuhi melalui bermain, baik bermain sendiri maupun bersama-sama dengan teman dalam suatu kelompok. Jadi bermain merupakan kebutuhan anak.

2 Kurikulum 2004 Standar Kompetensi Taman Kanak - Kanak dan Raudlatul Athfal, (Jakarta: Departemen Pendidikan Nasional, 2004), hal. 5 
Disinilah pentingnya media dan metode pembelajaran yang menarik agar minat belajar anak menjadi lebih tinggi dalam mempelajari huruf hijaiyah, karena dengan ketersediaan media pembelajaran yang edukatif dan menarik anak tidak akan merasa bosan dan bisa menambah pengalaman yang menarik ketika diberi materi pembelajaran bahasa arab/ huruf hijaiyah. Terkait hal ini, sukses tidaknya mengenalkan huruf bijaiyah seringkali dinilai dari segi metode yang digunakan. Metode bernyanyi dianggap salah satu metode yang tepat untuk mengenalkan huruf hijaiyah kepada anak usia dini karena bernyanyi mengajarkan kepada anak kecerdasan musikal, kecerdasan logis matematik, linguistik, interpersonal, dan intrapersonal. ${ }^{3}$ Selain itu, metode pembelajaran yang dianggap bisa digunakan untuk belajar mengenalkan huruf bijaiyah pada anak usia dini adalah dengan menggunakan media boneka Upin-Ipin. ${ }^{4}$ Sebab dalam upaya mengenalkan huruf hijaiyah pada anak usia dini dengan media boneka Upin-Ipin ini agar lebih mudah meresap dalam memori ingatan anak. Lebih dari itu, dengan menggunakan boneka UpinIpin pembelajaran tidak terkesan membosankan karena seolah-olah mereka sedang bermain, sehingga anak akan lebih mudah menerima materi pelajaran bahasa arab/huruf hijaiyah.

Darisini, studi ini tertarik untuk memfokuskan pada penerapan permainan boneka Upin-Ipin dalam pembelajaran anak usia dini agar anak dapat belajar aktif, menyenangkan, sehingga kemampuan anak dalam mengenal huruf hijaiyah dapat meningkat. Hal ini berdasarkan asumsi bahwa permainan boneka Upin-Ipin merupakan salah satu metode bermain yang cukup efektif untuk mengembangkan kemampuan mengenal huruf bijaiyah karena anak pada usia 3-4 tahun masih tahap pra operasional yaitu anak belajar melalui benda kongkret, yakni boneka Upin-Ipin. Ringkasnya, studi ini tertarik untuk membahas efektifitas penerapan penggunaan media boneka Upin-Ipin dalam pembelajaran sebagai upaya untuk meningkatkan kemampuan mengenal huruf hijaiyah pada anak kelompok A di Pos PAUD Bougenville 2 Ngawen Sidayu Gresik.

\section{Kajian teoretik}

\section{Kemampuan Mengenal Huruf}

Kemampuan secara kata dapat diartikan sebagai kesanggupan, kekuatan, kekuasaan atau kebolehan untuk melakukan sesuatu. Sesuatu yang dimaksud merupakan aspek yang dituju, dalam hal kajian ini tentunya kesanggupan untuk mengenali huruf hijaiyah. Mengenal juga dapat diartikan sebagai kenal, mengetahui, mempunyai rasa. Lebih lengkapnya kemampuan siswa mengenal huruf hijaiyah adalah semua kompetensi yang ada pada diri seorang siswa diwujudkan dalam kesanggupan untuk mengetahui baik itu bersifat lisan maupun tulisan terhadap objek yang diamati yaitu huruf hijaiyah. Kesanggupan untuk mengetahui baik lisan maupun tulisan yang dilakukan merupakan hasil belajar siswa.

Hasil belajar merupakan akibat dari kegiatan belajar yang diperoleh peserta didik setelah melakukan kegiatan belajar. Dari proses kegiatan belajar terjadi perubahan tingkah laku dalam diri seseorang yang merupakan hasil belajar yang diperoleh dari proses belajar. Usman menyatakan bahwa "seseorang yang telah mengalami proses belajar, akan mengalami perubahan tingkah laku, baik aspek pengetahuan, keterampilan maupun sikapnya". ${ }^{5}$

Definisi kemampuan adalah daya seseorang untuk melakukan sesuatu. Sedangkan bahasa adalah

\footnotetext{
${ }^{3}$ Halimah, dkk. Peningkatan Pengenalan Huruf Hijaiyah Melalui Metode Bernyanyi Pada Anak Usia 5-6 Tahun. Jurnal Pendidikan dan Khatulistiwa. (Vol. 5, No. 5, 2016). http://jurnal.untan.acid/index.php/jpdpb/artide/view/ 15424

${ }^{4}$ Bahran Taib. Penerapan Media Balok Untuk Meningkatkan Kemampuan Belajar Huruf Hijaiyah Pada Kelompok B TK Sandhy Putra Telkom Ternate. Edukasi Jurnal Pendidikan. (Vol.15, No.1 Januari 2017). ISSN: 1693-4164

${ }^{5}$ Muh. Uzer Usman. Menjadi Guru Profesional. (Bandung: Universiti Press, 1995), hal. 5.
}

\section{Nina, Azizah - Efektifitas Media Boneka Upin-Ipin dalam Meningkatkan Kemampuan Mengenal Huruf Hijaiyah}


penguasaan alat komunikasi, baik secara lisan, tertulis, maupun menggunakan tanda-tanda dan isyarat. Bahasa merupakan alat komunikasi utama bagi anak untuk mengungkapkan berbagai keinginannya maupun kebutuhannya. Jadi kemampuan huruf adalah daya yang dimiliki anak dari sebuah proses belajar mengajar dalam hal kemampuan berkomunikasi ${ }^{6}$. Faktor-faktor yang mendukung kemampuan mengenal huruf diantaranya adalah: 1) Bertambahnya umur anak 2) Kesehatan fisik dan mental anak 3) Lingkungan tempat anak tumbuh dan berkembang 4) Kecerdasaran anak 5) Status ekonomi orang tua

\section{Mengenal Huruf Hijaiyah}

Huruf adalah tanda aksara dalam tata tulis yang merupakan anggota abjad yang melambangkan bunyi dan bahasa. Menurut Ath Thabari menjelaskan bahwa huruf hijaiyah adalah salah satu jenis bahasa yang khas yang ditampilkan dalam Al Qur'an. Al Qur'an memang disusun menggunakan huruf Hijaiyah dengan makhrajyang berbeda sekaligus mengisyaratkan bahwa Al Qur'an diturunkan menggunakan bahasa arab.7 Pengertian mengenal huruf untuk pendidikan anak usia dini, yaitu anak belajar mengenali huruf dan bunyinya dari konteksnya dari bahasa yang digunakan. Anak diarahkan untuk mengidentifikasi bentuk huruf dan bunyinya. Jadi anak belajar dari konsep menyeluruh menuju ke konsep yang khusus. ${ }^{8}$ Dalam hal ini konsep menyeluruh yang dikenalkan kepada anak adalah huruf-hurufhijaiyah yang berjumlah 28 huruf, sementara konsen khusus yang dikenalkan adalah bentuk-bentuk huruf dan bunyinya. Mengingat siswa yang diajar adalah anak usia dini yang masih duduk di kelompok A dengan usia antara 3-4 tahun, maka dari ke-28 huruf hijaiyah, anak diarahkan untuk paham bahwa ke-28 huruf yang dikenalkan itu adalah huruf hijaiyah, sementara mengingat usia mereka yang masih dini, diharapkan sekurang-kurangnya siswa mampu mengenal 10-15 huruf dari ke-28 huruf hijaiyah yang dikenalkan.

Sedangkan huruf häaiyah, secara bahasa memilki arti huruf seperti yang kita kenal dalam bahasa Indonesia yang terdiri dari 26 huruf. Sedangkan dalam bahasa arab terdapat 28 huruf yang kita kenal dengan huruf hijaijah. Berdasarkan uraian tersebut di atas dapat disimpulkan bahwa kemampuan mengenal huruf hijaiyyah adalah penguasaan mengenali huruf-huruf dan bunyi dari huruf hijaiyyah yang berjumlah 28 berdasarkan bentuk, bunyi dan konteksnya dari bahasa yang digunakan, dalam hal ini bahasa Al Qur'an.

Kata huruf berasal dari bahasa arab harf atau huruuf. Huruf arab disebut juga huruf hija'iyah. Kata hija'iyah berasal dari kata kerja hajjaa yang artinya mengeja, menghitung huruf, membaca huruf demi huruf. Otory Surasman mengemukakan bahwa "huruf hijaiyah merupakan kunci dasar mampu membaca Al Qur'an'. Huruf hijaiyah digunakan sebagai ejaan untuk menulis kata atau kalimat dalam AL-Qur'an". Huruf hijaiyah disebut juga alphabet arab. Kata alphabet itu sendiri berasal dari bahasa arab alif, ba', ta'10.Kata abjad juga berasal daribahasa arab a-ba-ja-dun; alif,ba " ,ta " ,im dan dal. Namun ada pula yang menolak pendapat ini dengan alasan, huruf hijaiyah mempunyai aturan urutan yang berbeda dengan terminology abjad.

Huruf hijaiyah dimulai dari alif dan berakhir pada huruf $y a^{\prime}$ secara terpisah-pisah. Huruf hijaiyah adalah huruf-huruf yang digunakan sebagai dasar pembelajaran membaca Al Qur'an. Sedangkan huruf hijaiyah secara lebih rinci adalah kumpulan huruf-huruf yang berjumlah huruf yang terpakai dalam Al Qur'an dan dikenal hingga masa sekarang'11. Anak perlu dikenalkan dengan huruf-

\footnotetext{
${ }^{6}$ http:/ / ejournal.unp.ac.id/index.php/paud/artide/viewFile/1651/1421 (20/1/14 : 10-40)

7 Tabroni Rusyan, Cece Wijaya. Kemampuan Dasar Guru dalam Proses Belajar Mengajar. (Bandung: PT. Remaja Rosdakarya, 2003), hal. 27.

8 Ahmad Susanto. Perkembangan Anak Usia Dini. (Jakarta: Kencana Prenada Media group,2011) hal. 86

${ }^{9}$ Suprayogo, Imam \& Tabroni.. Metodologi Sosial Agama. (Bandung: PT.remaja Rosdakarya, 2003), hal. 52.

${ }^{10}$ Husain Abdul Karim. Pendidikan Anak Usia Dini. (Jogjakarta: Diva Pers, 1988), hal. 66.

${ }^{11}$ Acep Lim Abdurohim. Pedoman Ilmu Tajwid Lengkap.(Bandung: Diponegoro,2013), hal. 17
} 
huruf yang menyusun tulisan untuk membantu proses membacanya begitu juga dengan perlu dikenalkan huruf hiajiyah untuk dapat membaca Al Qur'an.

Kemampuan membaca pada anak usia dini dapat distimulasi dengan cara melatih memperdengarkan bunyi huruf, kata-kata tentang benda dan memperlihatkan bentuk huruf dan bendanya. ${ }^{12}$ Sejalan dengan itu huruf hijaiyah sangat perlu dikenalkan kepada anak sejak usia dini. Huruf hijaiyah terdiri dari dua kata yaitu huruf dan hijaiyah. Huruf adalah bentuk jamak dari al -harfu yang berarti bagian terkecil dari lafal yang tidak dapat membentuk makna tersendiri kecuali harus dirangkai dengan huruf lain. Huruf dalam bahasa Arab disebut hijaiyah. Asal mulanya berasal dari perkembangan sistem huruf di Mediteriania kuno yang dapat dilacak sudah mulai sejak peradaban Mesir muncul pada 2000 SM ${ }^{13}$.Jadi penyebutan hijaiyah adalah berasal dari bahasa arab yang memiliki sejarah tersendiri. Kemampuan mengenal huruf merupakan bagian dari aspek perkembangan bahasa anak, yang perlu dikembangkan dengan memberi stimulasi secara optimal sejak usia dini. Stimulasi pengenalan huruf adalah merangsang anak untuk mengenali, memahami, dan menggunakan simbol tertulis untuk berkomunikasi. Sejalan dengan itu pengenalan huruf hijaiyah dianggap penting.

\section{Metode Penelitian}

Studi ini merupakan penelitian tindakan kelas (PTK). Menurut menurut Arikunto PTK merupakan penelitian yang dilakukan oleh guru di dalam kelas bekerja sama dengan peneliti melalui refleksi diri, yang menekankan pada penyempurnaan atau peningkatan proses pembelajaran. PTK berfokus pada permasalahan praktis, yaitu permasalahan proses pembelajaran yang terjadi di kelas yang bertujuan memperbaiki dan meningkatkan proses pembelajaran yang sudah dilaksanakan guru serta mencari jawaban ilmiah bagaimana hal tersebut dapat dipecahkan dengan tindakan yang dilakukan ${ }^{14}$.

Dalam konteks studi ini, penelitian yang dilakukan ini bertujuan untuk mengetahui penggunaan media boneka Upin-Ipin dalam mengenal huruf hijaiyah kelompok A di Pos Paud Bougenville 2 Ngawen Sidayu Gresik. Penelitian tindakan kelas ini dilaksanakan dalam 2 siklus, tiap siklus dilaksanakan 2 kali pertemuan sebagai berikut:

1. Pelaksanaan Tindakan pada Siklus I

a. Perencanaan

Menurut Wahid Murni dan Nur Ali "perencanaan adalah kegiatan perancangan untuk pemecahan masalah." 15 Dalam tahapan ini peneliti menjelaskan tentang apa, mengapa, kapan, dimana, oleh siapa, dan bagaimana tindakan tersebut dilakukan. Perencanaan adalah langkah yang dilakukan guru ketika akan memulai tindakannya. Pada tahap ini, peneliti membuat perencanaan peneliti yang matang untuk mencapai pembelajaran yang diinginkan. Adapun langkah-langkah perencanaannya adalah sebagai berikut:

1) Observasi dan wawancara untuk mendapat gambaran awal tentang objek penelitian secara keseluruhan dan proses pembelajaran di POS PAUD Bougenville 2 Ngawen Sidayu Gresik. 2) Melakukan identifikasi permasalahan dalam pelaksanaan pembelajaran selanjutnya merumuskan persoalan bersama-sama antara guru dengan peneliti, baik yang menyangkut permasalahan guru maupun peserta didik. 3) Menyusun perangkat pembelajaran, antara lain: menentukan tema dan sub tema apa yang akan

\footnotetext{
12 Rasyid. Asesmen perkembangan anak usia dini.(Yogyakarta: Gama Media, 2012), Hal.110

13 Tadkiroatun Musfiroh. Menumbubkembangkan Baca Tulis Anak Uisa Dini. (Jakarta:Grasindo, 2009), hal. 19

${ }^{14}$ Suharsimi Arikunto, Dkk, Penelitian Tindakan Kelas. (Jakarta: Bumi Aksara, 2006), hal.38.

15 Ibid., hal. 17
}

\section{Nina, Azizah - Efektifitas Media Boneka Upin-Ipin dalam Meningkatkan Kemampuan Mengenal Huruf Hijaiyah}


digunakan dalam penelitian, mempersiapkan sumber atau bahan dalam pembelajaran seperti menyusun rencana kegiatan harian $(\mathrm{RKH})$ secara kolaboratif antara peneliti dan guru. 4)Menyiapkan media, alat dan bahan pembelajaran. 5) Menyusun lembar observasi/lembar pengamatan proses pembelajaran(permainan mengenal huruf hijaiyah dengan media boneka Upin-Ipin).

b. Pelaksanaan

Pelaksanaan adalah implementasi dari rencana yang sudah dibuat. Setelah diperoleh gambaran keadaan di POS PAUD Bougenville2 Ngawen Sidayu Gresik pada saat kegiatan pengembangan kemampuan bahasa, aktifitas peserta didik, dan sarana belajar. Maka dilakukan tindakan yaitu, melalui pembelajaran menggunakan penerapan permainan media boneka Upin-Ipin. Tahap ini merupakan penerapan dari perencanaan yang telah disusun, yaitu sebagai berikut:

1.b.1. Kegiatan pendahuluan meliputi a) Guru mengucapkan salam untuk membuka pembelajaran. b) Guru melakukan komunikasi tentang kehadiran peserta didik.c) Membaca doa dan surat-surat pendek d) Bernyanyi dan tepuk-tepuk e) Mengkondisikan peserta didik agar siap untuk belajar. f) Mengkomunikasikan tema dan kegiatan yang akan dilakukang) Melakukan motivasi peserta didik melalui metode bercakap-cakap, bercerita,demonstrasiatau mengungkapkan fakta yang ada kaitannya dengan mengembangkan kemampuan bahasa anak.

1.b.2. Kegiatan Inti meliputi: a) Mempersiapkan media/alat yang akan digunakan permainan. b) Menyampaikan aturan permainan. c) Melakukan pemanasan sebelum permainan dimulai. d) Guru memberikan contoh dan memperagakan permainan. e) Guru membimbing anak dalam permainan. f) Guru memberikan reward kepada semua anak. g) Beristirahat makan bersama.

1.b.3 Kegiatan Penutup yang meliputi a) Tanyakan kepada peserta didik: "Apa yang telah dipelajari tentang pelajaran kita hari ini dan manfaat apa yang kita dapat?" b) Guru menyampaikan pembelajaran besok hari. c) Berdo'a untuk mengakhiri kegiatan pembelajaran.

\section{Observasi}

Menurut Wina Sanjaya observasi merupakan"teknik mengumpulkan data dengan cara mengamati setiap kejadian yang sedang berlangsung dan mencatatnya dengan alat observasi tentang hal-hal yang akan diteliti". 16 Pada prinsipnya, tahap observasi dilakukan selama penelitian berlangsung, yang meliputi kehadiran siswa, keaktifan siswa dalam kelompok, kesiapan siswa dalam mengikuti kegiatan pembelajaran. Pada tahap ini observer/pengamat melakukan observasi terhadap pelaksanaan tindakan dengan menggunakan lembar observasi mengenal huruf dengan media boneka Upin-Ipin kepada anak. Lembar observasi ini berbentuk tabel, pada kolom pertama berisi indikator pencapaian, pada kolom kedua yaitu hasil pencapaian (BB, MB, BSH, BSB). Pada kolom hasil pencapaian ini peneliti memberikan penilaian menggunakan ceklist. Peneliti menggunakan lembar observasi ini untuk mengetahui hambatan yang dialami anak didik selama proses pembelajaran berlangsung. Hasil pengamatan yang didapat digunakan untuk memperbaiki proses pembelajaran pada siklus berikutnya.

Pengamatan berfungsi sebagai proses dokumentasi, dampak dari tindakan dan menyediakan informasi untuk mengetahui dampak dari tindakan yang dilakukan, artinya melihat perubahan apa saja yang telah terjadi dalam proses pembelajaran dan hasil belajar peserta didik.

${ }^{16}$ Wina Sanjaya, Penelitian Tindakan Kelas (Jakarta: Kencana, 2009), hal.86. 


\section{Refleksi}

Menurut Latief, dalam bukunya Wahid Murni dan Nur Ali, mengatakan bahwa"refleksi adalah kegiatan menganalisis hasil pengamatan untuk menentukan sudahsejauh mana pengembangan permainan media boneka Upin-Ipin dengan mengenalkan huruf yang sedang diterapkan telah berhasil memecahkan masalah dan apabila belum berhasil, fokus apa saja yang menjadi penghambat kekurangan keberhasilan tersebut" ${ }^{17}$.

\section{Pelaksanaan Tindakan pada Siklus II}

Jika hasil dari kegiatan pengembangan bahasa melalui permainan media boneka Upin-Ipin pengenalan huruf pada penelitian siklus I belum mencapai 80\%. Maka akan dilanjutkan pada tindakan siklus II. Perencanaan pelaksanaan pada siklus II hampir sama dengan siklus I, akan tetapi pada siklus II mengalami perbaikan dari siklus I. Hasil observasi anak selama kegiatan pembelajaran dalam setiap siklusnya menjadi dasar untuk menentukan tindakan yang tepat dalam rangka meningkatkan kemampuan bahasa melalui media boneka Upin-Ipin.

\section{Hasil dan Pembahasan}

Data yang diperoleh dalam penelitian di lapangan ini diuraikan dalam beberapa tahapan dalam dua siklus pembelajaran yang dilakukan dalam proses belajar mengajar di kelas terkait penggunaan boneka Upin Ipin dalam pembelajaran huruf bijaiyah berikut ini:

\section{Pelaksanaan Tindakan pada Siklus I}

Sesuai dengan yang direncanakan pada siklus pertama ini terdiri dari empat tahap, yakni perencanaan, pelaksanaan, observasi, dan refleksi, seperti berikut ini:

Perencanaan (Planing). Pada tahap ini, peneliti membuat perencanaan yang matang untuk mencapai pembelajaran yang diinginkan. Adapun kegiatan perencanaan pembelajaran siklus I dilakukan pada tanggal 7 Maret 2020 Pukul 07.00 WIB sampai dengan 09.30 WIB. Adalah sebagai berikut: 1) Penyusunan rencana pelaksanaan pembelajaran harian (RPPH), 2) Membuat media pembelajaran (boneka bijaiyah), 3) Membuat lembar penugasan untuk anak, 4) Menyiapkan lingkungan pembelajaran, 5) mengamati tingkat perkembangan anak

Pelaksanaan (Acting). Pelaksanaan adalah implementasi dari rencana yang sudah dibuat sebagai berikut; 1) Kegiatan Pembuka meliputi, a) Guru membuka dengan salam, do "a dan syahadat,b) Guru mengkondisikan siswa tentang kehadiran peserta didik, c) Guru mengkomunikasikan tentang media dan aturan saat bermain d) Menyanyikan lagu huruf hijaiyah. 2) Kegiatan Inti meliputi a) Guru mengajak anak untuk mengamati kegiatan yang sedang dilakukan b) Guru mendemontrasikan macam-macam huruf bijaiyah c) Anak menyebutkan huruf bijaijah yang ditempelkan pada boneka Upin-Ipin. 3) Kegiatan Penutup meliputi a) Anak diajak merapikan mainan dan mengembalikan sesuai tempatnya b) Recalling atau guru mengajak anak untuk mengingat kembali kegiatan hari ini c) Guru menutup dengan salam dan do ${ }^{\text {ee }}$.

Observasi dan Evaluasi. Kegiatan observasi pada saat pembelajaran digunakan untuk mengetahui penguasaan huruf hijaiyah, semangat, keaktifan, minat dan motivasi anak didik dalam mengikuti pembelajaran pengenalan huruf hijaiyah dengan menggunakan media boneka UpinIpin.Dalam kegiatan ini, anak dapat mengenal atau menunjukkan huruf, melafalkan dan menebali huruf sesuai aturan yang disampaikan.

Refleksi. Guru mengadakan refleksi dan evaluasi mengenai keberhasilan Penelitian Tindakan

17 
Kelas yang dilakukan dan bagaimana ketercapaiannya terhadap siswa. Berdasarkan hasil refleksi ini dapatdiketahui kelemahan kegiatan pembelajaran yang dilakukan oleh guru pada siklus berikutnya. Pada sikkus I terdapat kendala dan peneliti harus mencari solusi untuk mengatasi kendala yang dihadapi. Dalam halini kendala yang dihadapi adalah a) Sebagian siswa kurang memperhatikan penjelasan dari guru b) Guru kurang dapat membagi perhatiannya kepada semua anak, karena terdapat anak yang terus meminta perhatian. c) Ada huruf yang muda diingat anak dan ada pula huruf yang sulit diingat anak karena masih asing bagi mereka dan sulit pengucapan nya karena kurang terbiasa.

Sedangkan cara mengatasi dari kendala tersebut adalah guru melakukan tindakan agar pada siklus berikutnya tidak terjadi kendala yang sama dengan cara berikut: a) Guru mengkondisikan siswa dengan membuat tepuk maupun nyanyian yang baru agar anak lebih memperhatikan b) Guru mengganti posisi duduk anak yang meminta perhatian lebih didekat tempat duduk guru c) Guru memberi motivasi dan semangat agar mereka dapat menguasai pembelajaran yang diberikan.

\section{Pelaksanaan Tindakan Pada Siklus II .}

Siklus kedua tidak jauh berbeda seperti pada siklus pertama yaitu terdiri dari perencanaan, pelaksanaan, pengamatan, observasi, dan refleksi. Dari hasil obrservasi pada siklus II ini didapati hasil yang berbeda dari siklus I. Hasil observasi aktivitas siswa dalam bermain dengan media boneka Upin-Ipin selama siklus kedua dapat dilihat pada tabel 2. Sedangkan dalam proses refleksi siklus II tampak adanya peningkatan kemampuan membaca huruf bijaijah, yakni:

1) Aktivitas siswa dalam PBM menggunakan media boneka Upin-Ipin sudah (mampu menunjukkan huruf hijaiyah dengan bunyinya, mengenal huruf hijaiyah dengan boneka Upin-Ipin, menyebutkan huruf hijaiyah secara urut dan acak). Siswa mampu memahami segala kegiatan yang diberikan guru, mereka juga melakukan suatu kerjasama yang baik dan mulai mampu berpartisipasi, mempraktikan hasil kerja dengan baik serta tepat waktu dalam melaksanakan kegiatan tersebut sesuai dengan apa yang telah direncanakan. Hal ini dapat dilihat dari hasil observasi terhadap kemampuan mengenal huruf hijaiyah dengan media boneka Upin-Ipin yang meningkat dari prosentase keseluruhan $50 \%$ pada siklus pertama menjadi prosentase keseluruhan $80 \%$ pada siklus kedua.

Tabel 1

Hasil Rekapitulasi Observasi Kemampuan mengenal huruf hijaijab Kelompok A POS PAUD Bougenville 2 Ngawen Sidayu Gresik Pada Siklus I

\begin{tabular}{|c|c|c|c|c|c|c|c|c|c|c|c|c|c|c|c|}
\hline \multirow{4}{*}{ No } & \multirow{4}{*}{ NAMA } & \multicolumn{11}{|c|}{ Indikator } & \multirow{4}{*}{$\begin{array}{c}\text { Ju } \\
\text { ml } \\
\text { ah } \\
\text { Per } \\
\text { ole } \\
\text { ha } \\
\text { n }\end{array}$} & \multirow{4}{*}{$\begin{array}{c}\text { Pro } \\
\text { sen } \\
\text { tas } \\
\text { e } \\
\text { Per } \\
- \\
\text { Sis } \\
\text { wa }\end{array}$} & \multirow{4}{*}{ Ket } \\
\hline & & \multirow{2}{*}{\multicolumn{4}{|c|}{$\begin{array}{c}\text { Mengenal/men } \\
\text { unjuk huruf } \\
\text { hijaiyah }\end{array}$}} & \multirow{2}{*}{\multicolumn{3}{|c|}{$\begin{array}{c}\begin{array}{c}\text { Menebali/me } \\
\text { nulis huruf } \\
\text { hijaiyah }\end{array} \\
\begin{array}{c}\text { Pertemuan ke } \\
\text { 2(8/3/2020) }\end{array}\end{array}$}} & \multirow{2}{*}{\multicolumn{4}{|c|}{$\begin{array}{c}\begin{array}{c}\text { Melafalkan } \\
\text { huruf hijaiyah }\end{array} \\
\begin{array}{c}\text { Pertemuan ke } 3 \\
(9 / 3 / 2020)\end{array}\end{array}$}} & & & \\
\hline & & & & & & & & & & & & & & & \\
\hline & & 1 & 2 & 3 & 4 & \begin{tabular}{ll|l}
1 & 2 \\
\end{tabular} & 3 & 4 & 1 & 2 & 3 & 4 & & & \\
\hline 1 & Aura & $\sqrt{ }$ & & & & $\sqrt{ }$ & & & & $\sqrt{ }$ & & & 5 & 42 & \\
\hline 2 & Farah & & $\sqrt{ }$ & & $\sqrt{ }$ & v & & & & $\sqrt{ }$ & & & 5 & 42 & \\
\hline 3 & Arsyil & & & $\sqrt{ }$ & & & $\sqrt{ }$ & & & & $\sqrt{ }$ & & 9 & 75 & Tertinggi \\
\hline 4 & Al Afasy & & $\sqrt{ }$ & & & $\sqrt{ }$ & & & & $\sqrt{ }$ & & & 6 & 50 & \\
\hline 5 & Baihaqi & $\sqrt{ }$ & & & $\checkmark$ & & & & $\sqrt{ }$ & & & & 3 & 25 & Terendah \\
\hline 6 & Ayunda & & & $\sqrt{ }$ & & & $\sqrt{ }$ & & & & $\sqrt{ }$ & & 9 & 75 & Tertinggi \\
\hline 7 & Irsyam & & $\sqrt{ }$ & & & $\sqrt{ }$ & & & $\sqrt{ }$ & & & & 5 & 42 & \\
\hline 8 & Aliyah & & & $\sqrt{ }$ & & & $\sqrt{ }$ & & & & $\sqrt{ }$ & & 9 & 75 & Tertinggi \\
\hline 9 & Ikhsan & & $\sqrt{ }$ & & & $\sqrt{ }$ & & & & $\sqrt{ }$ & & & 6 & 50 & \\
\hline 10 & Riadi & $\sqrt{ }$ & & & $\sqrt{ }$ & & & & $\sqrt{ }$ & & & & 3 & 25 & Terendah \\
\hline 11 & Naila & $\sqrt{ }$ & & & $\sqrt{ }$ & & & & & $\sqrt{ }$ & & & 4 & 33 & \\
\hline 12 & Arsyi & $\sqrt{ }$ & & & & $\sqrt{ }$ & & & & $\sqrt{ }$ & & & 5 & 42 & \\
\hline 13 & Cilla & & $\sqrt{ }$ & & & $\sqrt{ }$ & & & & $\sqrt{ }$ & & & 6 & 50 & \\
\hline 14 & Cut vera & & & $\sqrt{ }$ & & & $\sqrt{ }$ & & & & $\sqrt{ }$ & & 9 & 75 & Tertinggi \\
\hline 15 & Zamzami & $\sqrt{ }$ & & & & $\sqrt{ }$ & & & & $\sqrt{ }$ & & & 5 & 42 & \\
\hline 16 & Abdis & $\sqrt{ }$ & & & & $\sqrt{ }$ & & & $\sqrt{ }$ & & & & 4 & 33 & \\
\hline 17 & Nindy & & & $\sqrt{ }$ & & & $\sqrt{ }$ & & & & $\sqrt{ }$ & & 9 & 75 & Tertinggi \\
\hline & & & & & umlah & & & & & & & & 102 & 850 & \\
\hline & & & & Pros & entase & e $\%$ & & & & & & & & 5 & \\
\hline
\end{tabular}


2) Meningkatnya aktivitas guru dalam PBM didukung oleh meningkatnya aktivitas guru dalam mempertahankan dan meningkatkan suasana pembelajaran meningkatkan kemampuan mengenal huruf hijaiyah dengan media boneka Upin-Ipin. Guru dengan semangat yang tinggi dan penuh intensif membimbing siswa saat mengalami kesulitan dalam PBM (mengenal/menunjukkan huruf hijaiyah, menebali/menulis huruf bijaijah dan melafalkan huruf hijaiyah) pada siklus I, (mampu menunjukkan huruf hijaiyah dengan bunyinya, mengenal huruf bijaiyah dengan boneka Upin-Ipin, menyebutkan huruf bijaiyah secara urut dan acak) pada siklus II dapat dilihat dari hasil observasi aktivitas siswa dalam PBM meningkatnya dari terendah 25\% pada siklus pertama menjadi $67 \%$ pada siklus kedua.

\section{Tabel 2}

Data Hasil Rekapitulasi Observasi Kemampuan mengenal huruf hijaiyah Kelompok A POS PAUD Bougenville 2 Ngawen SidayuGresik Pada Siklus II

\begin{tabular}{|c|c|c|c|c|c|c|c|c|c|c|c|c|c|c|}
\hline \multirow{3}{*}{ so } & \multirow{3}{*}{ NAMA } & \multicolumn{10}{|c|}{ Indikator } & \multirow{3}{*}{$\begin{array}{c}\mathrm{ml} \\
\mathrm{ah} \\
\text { Per } \\
\text { ole } \\
\text { ha } \\
\mathrm{n}\end{array}$} & \multirow{3}{*}{$\begin{array}{l}\text { Prose } \\
\text { ntase } \\
\text { Per- } \\
\text { Siswa }\end{array}$} & \multirow{3}{*}{ Ket } \\
\hline & & \multirow{2}{*}{\multicolumn{4}{|c|}{$\begin{array}{c}\begin{array}{c}\text { Menunjukkaan } \\
\text { Huruf } \\
\text { Hijaiyah dan } \\
\text { bunyinya }\end{array} \\
\begin{array}{c}\text { Pertemuanke } \\
1(11 / 3 / 2020)\end{array}\end{array}$}} & \multirow{2}{*}{\multicolumn{3}{|c|}{$\begin{array}{c}\text { Mengenal } \\
\text { Huruf } \\
\text { Hijaiyah } \\
\text { dengan } \\
\text { Boneka Upin- } \\
\text { Ipin } \\
\begin{array}{c}\text { Pertemuanke } \\
\text { 2 (12/3/2020) }\end{array}\end{array}$}} & \multicolumn{3}{|c|}{\begin{tabular}{|c|} 
Ju \\
Menyebutkan \\
Huruf Hijakyah \\
secara urut dan \\
acak
\end{tabular}} & & & \\
\hline & & & & & & & & & \multicolumn{3}{|c|}{$\begin{array}{c}\text { Pertemuan ke } 3 \\
(\mathbf{1 4 / 3 / 2 0 2 0 )}\end{array}$} & & & \\
\hline & & 1 & 2 & 3 & 4 & $1 \mid 2$ & 3 & 4 & $1 \mid 2$ & 3 & 4 & & & \\
\hline 1 & Aura & & & $\sqrt{ }$ & & & $\sqrt{ }$ & & & $\sqrt{ }$ & & 9 & 75 & \\
\hline 2 & Farah & & & & $\sqrt{ }$ & & $\sqrt{ }$ & & & $\sqrt{ }$ & & 10 & 83 & \\
\hline 3 & Arsyil & & & & $\sqrt{ }$ & & & $\sqrt{ }$ & & $\sqrt{ }$ & & 11 & 92 & Tertinggi \\
\hline 4 & Al Afasy & & & $\sqrt{ }$ & & & $\sqrt{ }$ & & & $\sqrt{ }$ & & 9 & 75 & \\
\hline 5 & Baihaqi & & & $\sqrt{ }$ & & & $\sqrt{ }$ & & $\sqrt{ }$ & & & 8 & 67 & Terendah \\
\hline 6 & Ayunda & & & & $\sqrt{ }$ & & & $\sqrt{ }$ & & $\sqrt{ }$ & & 11 & 92 & Tertinggi \\
\hline 7 & Irsyam & & & $\sqrt{ }$ & & & $\sqrt{ }$ & & & $\sqrt{ }$ & & 9 & 75 & \\
\hline 8 & Aliyah & & & & $\sqrt{ }$ & & & $\sqrt{ }$ & & $\sqrt{ }$ & & 11 & 92 & Tertinggi \\
\hline 9 & Ikhsan & & & & $\sqrt{ }$ & & & $\sqrt{ }$ & & $\sqrt{ }$ & & 11 & 92 & Tertinggi \\
\hline 10 & Riadi & & & $\sqrt{ }$ & & & $\sqrt{ }$ & & $\sqrt{ }$ & & & 8 & 67 & Terendah \\
\hline 11 & Naila & & & $\sqrt{ }$ & & & $\sqrt{ }$ & & & $\sqrt{ }$ & & 9 & 75 & \\
\hline 12 & Arsyi & & & $\sqrt{ }$ & & & & $\sqrt{ }$ & & $\sqrt{ }$ & & 10 & 83 & \\
\hline 13 & Cilla & & & $\sqrt{ }$ & & & $\sqrt{ }$ & & & $\sqrt{ }$ & & 9 & 75 & \\
\hline 14 & Cut vera & & & & $\sqrt{ }$ & & & $\sqrt{ }$ & & $\sqrt{ }$ & & 11 & 92 & Tertinggi \\
\hline 15 & Zam zami & & & $\sqrt{ }$ & & & $\sqrt{ }$ & & & $\sqrt{ }$ & & 9 & 75 & \\
\hline 16 & Abdis & & & $\sqrt{ }$ & & & $\sqrt{ }$ & & $\sqrt{ }$ & & & 8 & 67 & Terendah \\
\hline 17 & Nindy & & & & $\sqrt{ }$ & & $\sqrt{ }$ & & & & $\sqrt{ }$ & 11 & 92 & Tertinggi \\
\hline \multicolumn{12}{|c|}{ Jumlah } & 164 & 1367 & \\
\hline \multicolumn{12}{|c|}{ Prosentase \% } & \multicolumn{3}{|c|}{80} \\
\hline
\end{tabular}


3) Meningkatnya aktivitas siswa dalam (mengenal/menunjukkan huruf hijaiyah, menebali/ menulis huruf hijaiyah dan melafalkan huruf hijaiyah) pada siklus I, dan meningkatnya aktivitas siswa dalam (menunjukkan huruf hijaiyah dengan bunyinya, mengenal huruf hijaiyah dengan boneka Upin-Ipin, menyebutkan huruf hijaiyah secara urut dan acak) pada siklus II. Hal ini berdasarkan hasil nilai tertinggi prosentase Per-siswa $75 \%$ pada siklus I meningkat hasil nilai tertinggi prosentase menjadi $92 \%$ pada siklus II.

4) Meningkatnya prosentase keseluruhan (mengenal/menunjukkan huruf hijaiyah, menebali/menulis huruf hijaiyah dan melafalkan huruf hijaiyah) $50 \%$ pada siklus I, menjadi $80 \%$ prosentase keseluruhan (menunjukkan huruf hijaiyah dengan bunyinya, mengenal huruf hijaiyah dengan boneka Upin-Ipin,menyebutkan huruf hijaiyah secara urut dan acak) pada siklus II.

5) Siswa sudah tertarik mengikuti pembelajaran dari guru, bisa mengenal dan menyebutkan huruf hijaiyah.

\section{Grafik 3}

Prosentase Per-Siswa Siklus I dan Siklus II Kemampuan mengenal huruf hijaiyah Kelompok A POS PAUD Bougenville 2 Ngawen Sidayu Gresik

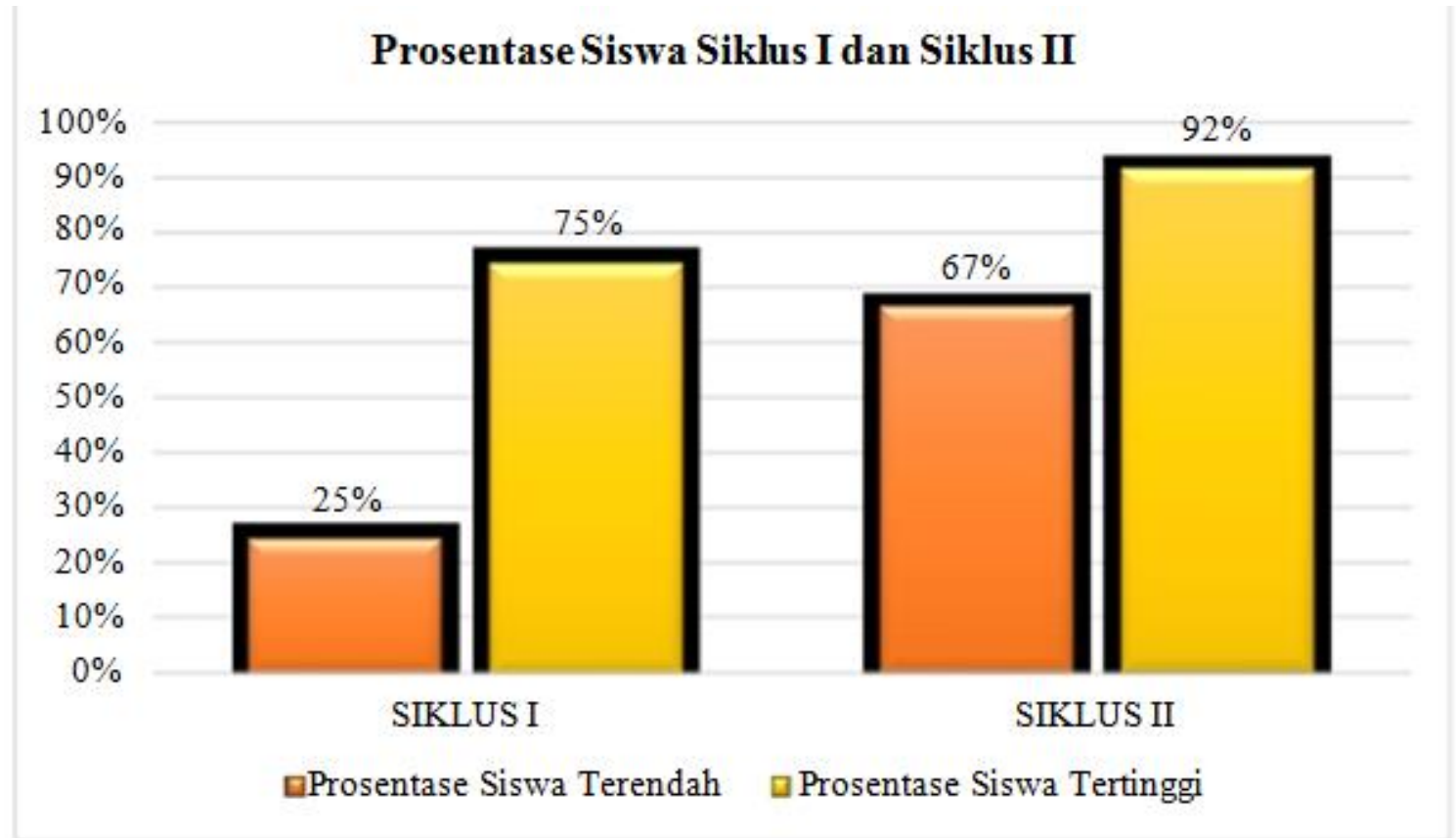

6) Siswa yang dulu belum bisa menyebutkan dan mengetahui hurufhijaiyah (Alif- Ba"- Ta"- Tsa"Jim) dengan menggunakan media boneka Upin-Ipin anak dapat mengembangkan kemampuan untuk menyebutkan/melafalkan huruf hijaiyah dengan lancar. Metode yang bervariasi akan menambah pengalaman anak dan juga pembelajaran akan berkesan dalam diri anak.

7) Siswa bergantian ditunjuk untuk bermain melafalkan dan menunjukkan huruf hijaiyah dengan menggunakan permainan boneka Upin-Ipin, anak akan mengekpresikan perasaanya ketika mendapat giliran permainan baru dan juga melatih kesabaran anak dalam pengembangan sosial emosional. 


\section{Grafik 4}

Prosentase Keseluruhan Siklus I dan Siklus II Kemampuan mengenal huruf hijaiyah Kelompok A POS PAUD Bougenville 2 Ngawen Sidayu Gresik

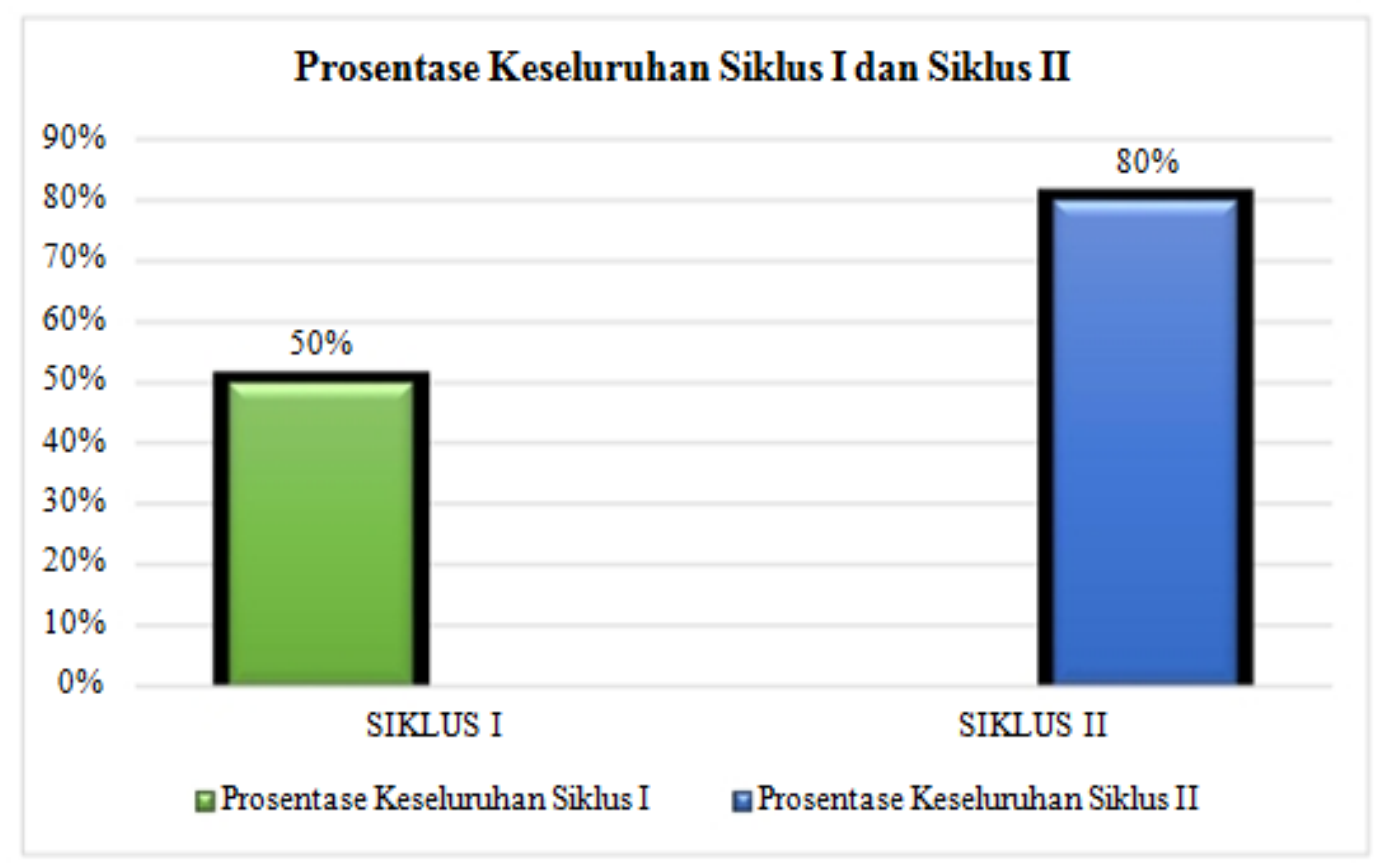

\section{Kesimpulan}

Berdasarkan hasil analisis data yang dipaparkan di atas, maka dapat disimpulkan bahwa melalui kegiatan PTK dalam dua siklus mulai dari siklus I, siklus II terlihat peningkatan kempuan siswa POS PAUD Bougenville 2 Ngawen Sidayu Gresik dalam membaca huruf hijaiyah melalui media boneka Upin-Ipin. Hal ini dapat dilihat dari perbandingan hasil observasi dan refleksi siklus I dan siklus II yang menunjukkan terjadinya peningkatan kemampuan siswa, yakni nilai per-siswa $75 \%$ pada siklus I meningkat menjadi $92 \%$ pada siklus II. Demikian halnya tampak dari prosentase keseluruhan pada siklus I (50\%)meningkat (80\%)pada prosentase keseluruhan pada siklus II. 


\section{Daftar Pustaka}

Bahran Taib. Penerapan Media Balok Untuk Meningkatkan Kemampuan Belajar Huruf Hijaiyah Pada Kelompok B TK Sandhy Putra Telkom Ternate. Edukasi Jurnal Pendidikan. (Vol.15, No.1 Januari 2017). ISSN: 1693-4164

Halimah, dkk. Peningkatan Pengenalan Huruf Hijaiyah Melalui Metode Bernyanyi Pada Anak Usia5-6 Tahun. Jurnal Pendidikan dan Khatulistiwa.(Vol. 5, No. 5, 2016). http://jurnal.untan.ac.id/index.php/jpdpb/article/view/15424

Kurikulum 2004 Standar Kompetensi Taman Kanak - Kanak dan Raudlatul Athfal, (Jakarta: Departemen Pendidikan Nasional, 2004).

Masnur Muslich. Melaksanakan Penelitian Tindakan Kelas Itu Mudah (Jakarta: Bumi Aksara, 2013).

Memahami Paradigma Baru Pendidikan Nasional dalam Undang-Undang Sistem Pendidikan Nasional, (Jakarta : Departemen Agama RI, 2003).

Sugiyono. Metode Pendidikan Pendekatan Kuantitatif, Kualitatif, dan R\&D (Bandung:Alfabeta, 2013).

Undang-Undang Sistem Pendidikan Nasional, (Jakarta: Departemen Pendidikan Nasional, 2015)

Wahidmurni, Nur Ali, Penelitian Tindakan Kelas (Malang: UM PRESS, 2008).

Wina Sanjaya. Penelitian Tindakan Kelas (Jakarta: Kencana, 2009). 